\title{
A filigrana da identidade nacional
}

\section{O corpo da Nação.}

COROSSACZ, Valeria Ribeiro.

Rio de Janeiro: UFRJ: 2009. (Coleção Etnologia).

O livro de Valéria Corossacz é resultado de pesquisa para doutoramento em Antropologia em programa de cooperação binacional entre universidades francesa e italiana. O sistema de classificação racial no Brasil é um dos eixos de análise da obra. A autora é bastante original e revigora o debate sobre a temática racial no Brasil. Corossacz não deixa dúvidas de que é crucial compreender as "relações raciais" para avaliar a realidade brasileira atual. A obra revitaliza as discussões sobre raça/cor e etnia, num percurso próprio.

O livro O corpo da Nação revela como a flexibilidade da classificação racial reordena múltiplas possibilidades classificatórias ou, como preferem alguns, "um gradiente de cores" para a construção de um sistema próprio. Trata-se de uma ferramenta ou dispositivo social que, por sua flexibilidade e uso diário, pode ser instrumentalizada nas mais diferentes situações do cotidiano e de relações de poder.

Esse livro cumpre a tarefa monumental de elucidar nexos relacionais entre sexo (construção da sexualidade), reprodução (biológica e social) e nação (identidade nacional). Para sua empreitada, parte de fundamentação teórica consolidada no campo das relações raciais produzidas recentemente, com a grande vantagem de um olhar etnográfico lapidado por um longo período de pesquisa de campo em que buscou compreender como se aplica - sistema de classificação racial nos documentos médicos; além disso, realizou pesquisa etnográfica em maternidades públicas do Rio, cujo resultado revela intenso contato com as mulheres e profissionais de saúde em diferentes posições, formações e atividades. Entrevistou mulheres intelectuais negras, representantes do movimento de mulheres negras e de saúde, pesquisadoras e pesquisadores, com destaque para Edna Roland e a Organização Não Governamental Criola, que tiveram grande atuação e produção teórica sobre a saúde reprodutiva e a saúde da população negra; acompanhou de perto a movimentação política de segmentos negros em busca do efetivo acesso à saúde; e investigou como se dá a escolha pela esterilização feminina, método privilegiado pelas mulheres brasileiras para o controle da fecundidade.

A autora lapidou sua tese sem se render às teses clássicas, já estabelecidas, e, ao optar por abordar o sistema de classificação racial brasileiro, sem se esquecer de conceitos fundamentais, faz sua obra sem os cansativos relatos cronológicos e as exposições lineares sobre o tema. Em um percurso inovador, $O$ corpo da Nação percorre temas centrais da antropologia para mostrar que no corpo se inscrevem relações sociais e de poder, bem como o racismo e o sexismo. E é no jogo das relações cotidianas que é tecida a identidade brasileira, reificada em práticas e discursos, procedimentos institucionais e ritos sociais.

E não é sem propósito que se descobre por meio de O corpo da Nação que é de dada estagnação, convertida em força ideológica, que se faz o 'mito da democracia racial'.

Penso que se trata de uma virtude de $O$ corpo da Nação revelar como se dá a reiteração e a negação do racismo e sexismo no cotidiano; e como esse forte componente ideológico se associa ambiguamente às práticas e aos procedimentos classificatórios que se reinventam no uso cotidiano.

E, assim, os modelos reprodutivos (biológicos e sociais), entremeados aos discursos sobre os destinos da Nação, por vezes se realizam em estratégicas controlistas agudizados por discursos higienistas e sexistas. Nesse sentido, a análise sobre a esterilização feminina no Brasil se estabelece como um dos pilares fundamentais de $\mathrm{O}$ corpo da Nação. Corossacz é perspicaz ao extrair da questão da esterilização inspiração para compreender a identidade nacional, partejada em características sociais e ideológicas singulares.

A presença/ausência da ideia de raça revela-se como a filigrana que dá a autenticidade à identidade nacional, plasticidade às relações raciais no Brasil, ou, como preferem alguns, cordialidade. 0 trabalho de Corossacz é único e genial por trazer à luz o fenômeno do nascimento não só como um acontecimento biológico, mas também em 
todo seu potencial social, cultural e político. Um fenômeno de magnitudes e repercussões tão amplas que faz pensar no necessário reconhecimento desde o nascimento para a construção de identidades plenas e livres do racismo e do sexismo.

Raquel Souzas

Universidade Federal da Bahia 